\title{
Kajian Ketumpatan Lineamen dalam Penilaian Potensi Jatuhan Batuan di Kawasan Lembah Kinta
}

(Study of Lineament Density in Potential Evaluation of Rock Fall in Kinta Valley)

\author{
MUHAMMAD FAHMI ABDUl GHANI*, NORBERT SimON, GOH THIAN LAI, \\ TUAN ROSLI TUAN MOHAMED \& ABDUL GHANI RAFEK
}

\begin{abstract}
ABSTRAK
Perbukitan batu kapur di Lembah Kinta membentuk landskap muka bumi yang unik dan indah hasil daripada proses pelarutan batuan karbonat. Namun begitu, bergantung kepada kawasan perbukitan batu kapur tersebut, kehadiran pelbagai struktur geologi seperti struktur retakan dan kekar yang ekstensif mampu memberi ancaman kepada manusia dan harta benda. Kajian ini bertujuan melihat hubungan antara ketumpatan lineamen dan tahap kestabilan tujuh cerun gunung batu kapur di Lembah Kinta, Malaysia. Kajian ini terbahagi kepada dua peringkat, iaitu pemetaan ketumpatan lineamen dan penilaian kestabilan cerun dengan menggunakan kaedah Kekuatan Jasad Batuan (RMS). Sebanyak 599 lineamen rantau dikenal pasti dengan panjang keseluruhan lineamen mencapai $317 \mathrm{~km}$. Seterusnya, peta ketumpatan lineamen yang dihasilkan dikelaskan kepada tiga kelas: Rendah (137.0-84.23) m, sederhana (84.22-46.83) m dan tinggi (46.82-0.0) m. Kaedah RMS yang dijalankan di lapangan pula adalah bertujuan bagi mengesahkan peta ketumpatan lineamen yang dihasilkan. Sebanyak dua belas stesen dinilai dengan tujuh parameter RMS iaitu kekuatan bahan batuan, tahap luluhawa, bukaan kekar, orientasi kekar, kelebaran kekar, ketakselanjaran dan aliran air bawah tanah. Setiap cerun yang dinilai dikelaskan kepada lima kumpulan daripada sangat lemah hingga sangat kuat. Skor RMS berdasarkan jumlah akhir setiap parameter yang dinilai. Hampir kesemua stesen yang dicerap berada pada kelas sederhana (Gunung Rapat, Datok, Kandu, Panjang, A, Tempurung) manakala hanya satu stesen (Gunung Lang) berada pada kelas lemah. Korelasi antara peta ketumpatan lineamen dan skor RMS menunjukkan korelasi yang baik dengan 73\% ketepatan. Ini menunjukkan bahawa kestabilan cerun di Lembah Kinta dipengaruhi secara langsung oleh ketumpatan lineamen rantau.
\end{abstract}

Kata kunci: Batu kapur; jatuhan batuan; kekuatan jasad batuan; ketumpatan lineamen; Lembah Kinta

\section{ABSTRACT}

Limestone hills in Kinta Valley formed a prominent natural beauty to the landscape due to its unique features formed by dissolution of carbonate rocks. However, depending from where the hill is situated, it may exposes threat to humans and properties due to the existence of many geological structures such as extensive joints and fractures. The purpose of this study was to examine the relationship between lineament density map and stability of seven limestone hills in Kinta Valley, Malaysia. Methods in this study were divided into two stages, namely the lineament density map and evaluation of the slope stability using the rock mass strength (RMS) method. A total of 599 lineaments were identified with the total length of 317 km. Lineament density map is further classified into three classes: Low (137.0-84.23), medium (84.22-46.83) and high (46.82-0.0). The purpose of RMS is to validate rockfall susceptibility as portrayed in the lineament density map. A total of 12 assessment stations for each of the hills were conducted using the rock mass strength system (RMS). The geological conditions of the hills were assessed by using seven components of the RMS, these are intact rock strength, weathering, joint width, joint orientation, joint width, discontinuity and ground water flow. Subsequently, the hills are classified into very strong, strong, moderate, weak, or very weak based on the sum of ratings for all the components. The results observed in the field showed that almost all stations are classified into the medium class (Gunung A, Rapat, Datok, Lang, Kandu, Panjang and Tempurung), only one station (Gunung Lang) is classified in the weak class. The lineament density map and the RMS scores are correlated well with 73\% accuracy. This shows that the stability of slopes in Kinta Valley is directly affected by regional lineament density.

Keywords: Kinta Valley; limestone; lineament density; rock fall; rock mass strength

\section{PENGENALAN}

Perbukitan batu kapur di Lembah Kinta membentuk landskap muka bumi yang menarik dan indah. Namun begitu, bergantung kepada kedudukan perbukitan tersebut, perbukitan batu kapur di Lembah Kinta terdedah kepada ancaman jatuhan batuan akibat proses luluhawa yang tinggi dan kehadiran struktur kekar dan retakan yang ekstensif. Kajian ini bertujuan melihat hubungan antara ketumpatan lineamen dan tahap kestabilan cerun di tujuh buah gunung batu kapur di Lembah Kinta. Tumpuan utama 
kajian ini adalah di sekitar kawasan Lembah Kinta, Perak yang sedang membangun dan telah dicadangkan untuk dibangunkan sebagai salah satu Geopark di Malaysia (Mohd Shafeea 2013).

Terdapat sekurang-kurangnya 57 buah bukit batu kapur di Negeri Perak Darul Ridzuan dengan 37 daripadanya terletak di Lembah Kinta dan lokasi utama terletak di Kramat Pulai dan Simpang Pulai (Abdullah Sani 1991; Aw 1996; Aw \& Ooi 1979; Ooi 1979). Proses pelarutan batu kapur yang berlaku di sepanjang bukaan rekahan oleh air hujan serta hakisan dan luluhawa menyebabkan rekahan tersebut bertambah besar dan seterusnya menyebabkan kegagalan akibat terpisah daripada jasad batuan (Chung 1981). Kepesatan pembangunan di Negeri Perak khususnya di sekitar kawasan Ipoh telah meningkatkan permintaan terhadap kawasan tanah yang menyebabkan pembinaan bangunan untuk kediaman dan juga industri telah menghampiri tebing curam batu kapur (JMG 2009).

Laporan mengenai kejadian jatuhan batuan di Lembah Kinta direkodkan seawal tahun 1919 (Jadual 1). Beberapa kes kejadian jatuhan batuan telah dilaporkan di sekitar Lembah Kinta seperti dalam Jadual 1.

\section{KAWASAN KAJIAN}

Kawasan kajian adalah di sekitar kawasan Lembah Kinta yang terletak di bahagian tengah Negeri Perak Darul Ridzuan yang meliputi kawasan seluas $1200 \mathrm{~km}^{2}$. Lembah Kinta dikelilingi oleh Banjaran Utama (Titiwangsa) di sebelah timur manakala Gunung Kledang pula membatasi
Lembah Kinta pada sebelah barat. Secara keseluruhannya, perbukitan batu kapur di Lembah Kinta mempunyai purata keluasan $1.08 \mathrm{~km}^{2}$. Sebahagian daripada gununggunung yang terdapat di Lembah Kinta tidak bernama dan sebahagian gunung-gunung batu kapur yang dikenal pasti ditunjukkan dalam Rajah 1. Terdapat juga dolina atau lubang benam yang tersingkap di Lembah Kinta yang kini dipenuhi dengan air tertabur dengan banyaknya di sekitar kawasan kajian.

\section{GEOLOGI AM LEMBAH KINTA}

Sebahagian besar daripada geologi kawasan Lembah Kinta terdiri daripada batu kapur yang membentuk morfologi kars seperti mogot, stalaktit, stalagmit, gua, kikisan lereng, jerungkau, alur pelarutan, kekar dan sesar. Nama Formasi Batu Kapur Kinta dicadangkan oleh Foo (1983) berdasarkan taburan batu kapur yang mendominasi sebahagian besar kawasan Lembah Kinta. Pada awalnya batu kapur ini dikenali dengan pelbagai nama oleh penyelidik berlainan, seperti Batu Kapur Kanthan (Metcalfe 1981), H.S. Lee beds, Nam Long beds, Kuan On beds, Thye On beds dan Kim Loong No.1 beds (Suntharalingam 1968). Ingham dan Bradford (1960) telah mencirikan batuan ini kepada tiga fasies batuan utama iaitu Fasies Berkapur, Berargilit dan Arsenit.

Rejahan granit terutamanya pada sebelah timur kawasan Lembah Kinta telah membawa kepada proses pemineralan bijih timah dan bijih lain seperti ilmenit dan tungsten di kawasan tersebut (Hutchison \& Tan 2009; Ingham \& Bradford 1960). Rejahan granit telah membentuk Banjaran

JADUAL 1. Rekod kejadian jatuhan batuan di sekitar Lembah Kinta (Simon et al. 2015)

\begin{tabular}{|c|c|c|}
\hline Lokasi & Tarikh Kejadian & Kerosakan/Kemalangan Jiwa \\
\hline $\begin{array}{l}\text { Bahagian hujung sebelah utara } \\
\text { Bukit Tunggal, Gopeng }\end{array}$ & 17 Disember 1919 & $\begin{array}{l}\text { Letupan udara merosakkan kawasan perumahan dan } \\
\text { kedai yang berada pada jarak } 200 \mathrm{~m} \text {. Maut: } 12 \text { orang }\end{array}$ \\
\hline $\begin{array}{l}\text { Bahagian hujung sebelah timur } \\
\text { Gunung Cheroh, Ipoh }\end{array}$ & 18 Oktober 1973 & $\begin{array}{l}\text { Puing meranapkan sebuah rumah panjang. Maut: } 40 \\
\text { orang }\end{array}$ \\
\hline $\begin{array}{l}\text { Bahagian hujung sebelah barat } \\
\text { Gunung Rapat, Kg. Sengat }\end{array}$ & 21 Oktober 1976 & $\begin{array}{l}\text { Puing merosakkan sebuah jentolak dan sebuah bas } \\
\text { pelancong }\end{array}$ \\
\hline $\begin{array}{l}\text { Bahagian timur Gunung } \\
\text { Tunggal, Gopeng }\end{array}$ & 29 Disember 1987 & Puing merosakkan sebuah pejabat. Maut: 1 orang \\
\hline $\begin{array}{l}\text { Bahagian hujung sebelah } \\
\text { selatan Gunung Bercham }\end{array}$ & 2 Disember 2004 & $\begin{array}{l}\text { Bangsal membuat tauhu kering yang berada pada jarak } \\
10 \mathrm{~m} \text { musnah. Maut: } 2 \text { orang, } 5 \text { orang tercedera }\end{array}$ \\
\hline $\begin{array}{l}\text { Kawasan kuari, Gunung } \\
\text { Karang Besar, Keramat Pulai }\end{array}$ & 5 Jun 2008 & $\begin{array}{l}\text { Kenderaan pacuan empat roda dan sebuah kren tertimbus } \\
\text { di bawah runtuhan batu. Maut: } 1 \text { orang }\end{array}$ \\
\hline $\begin{array}{l}\text { Kawasan Kilang Yee Lee } \\
\text { Edible Oils, Gunung Lang, } \\
\text { Ipoh }\end{array}$ & 13 Februari 2012 & $\begin{array}{l}\text { Sebahagian dinding blok pentadbiran kilang pecah, tiada } \\
\text { kemalangan jiwa dilaporkan }\end{array}$ \\
\hline $\begin{array}{l}\text { Kira-kira } 50 \text { m dari pintu } \\
\text { masuk utama Gua Tempurng } \\
\text { (Gua Tempurung, Kampar) }\end{array}$ & 11 April 2012 & $\begin{array}{l}\text { Tiada kemusnahan pada fasiliti dan kawasan sekitar serta } \\
\text { tiada kemalangan jiwa dilaporkan }\end{array}$ \\
\hline
\end{tabular}

Diubahsuai dari Aw (1996); Aw \& Ooi (1979); Chow (1995); Chow \& Sahat (1988); Chung (1981); Hashim (1991); Ooi (1979); Tuan Rusli Mohammed \& Ahmat Khairut Termizi (2012a \& 2012b) 


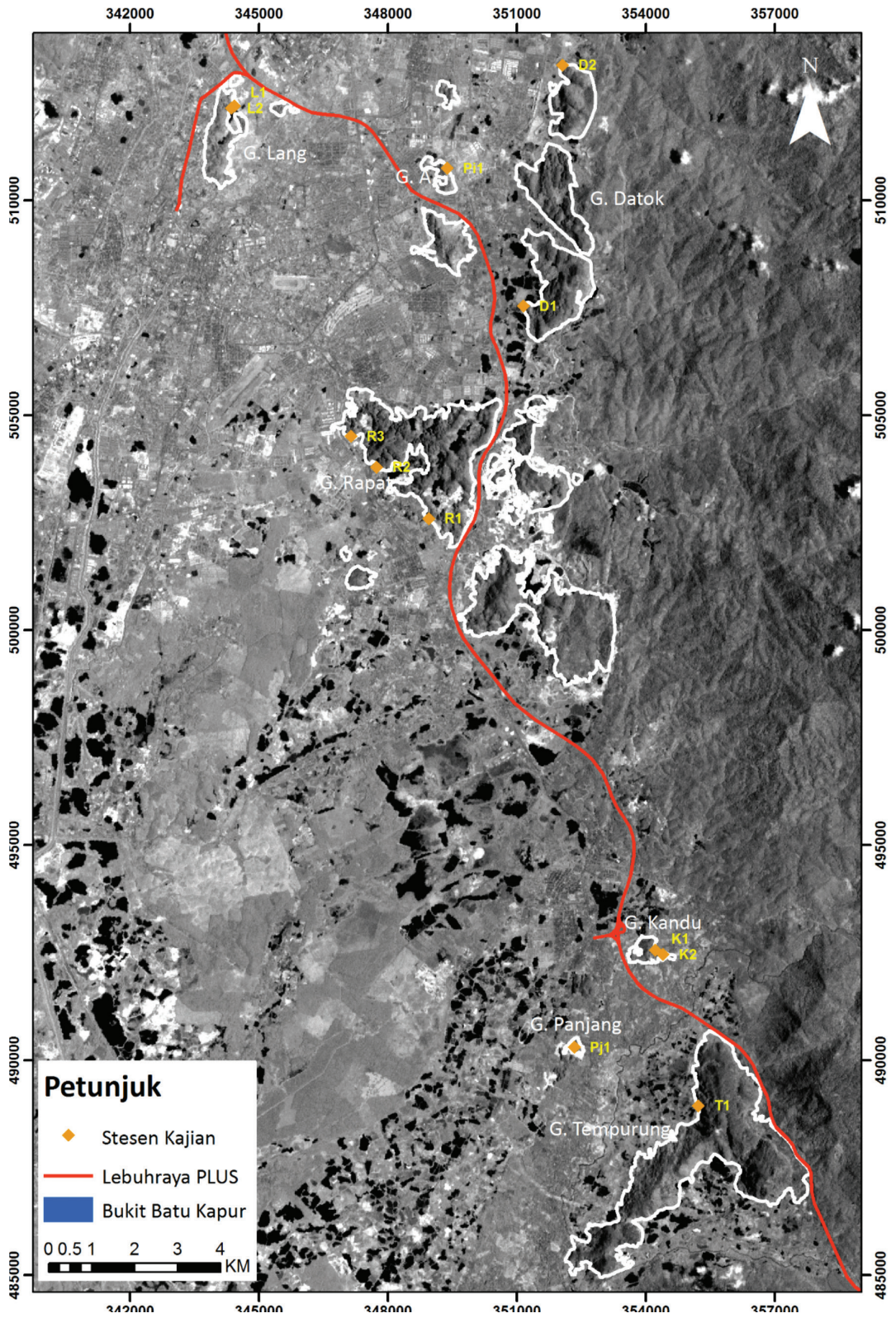

RAJAH 1. Imej satelit Landsat ETM+ (jalur pankromatik) yang digunakan dalam kajian ini serta lokaliti persempadanan batu kapur kawasan kajian

Besar berusia Trias dan mengubah sebahagian batu kapur di Lembah Kinta kepada marmar akibat daripada proses metamorfisme. Foo (1983) menyatakan bahawa Batu Kapur Kinta ini berusia daripada Silur hingga Perm berdasarkan kepada penemuan beberapa fosil konodon.

\section{KAEDAH KAJIAN}

Kajian ini dibahagikan kepada dua peringkat, pemetaan ketumpatan lineamen dan penilaian kestabilan cerun dengan menggunakan kaedah Kekuatan Jasad Batuan (RMS). Kedua-dua kaedah ini dikorelasikan secara langsung bagi mendapatkan kesahan data ketumpatan lineamen yang dihasilkan. Rajah 2 menunjukkan proses keseluruhan kaedah kajian yang dijalankan.

\section{PERINGKAT PERTAMA: PEMETAAN} KETUMPATAN LINEAMEN

Surihan lineamen tertumpu kepada bukit batu kapur sahaja dengan keseluruhan hasil kajian yang diperoleh menggambarkan tahap kekuatan bukit batu kapur. Imej Landsat ETM+ mentah diproses bagi mendapatkan data imej yang terbaik bagi memudahkan proses penyurihan lineamen secara visual atau manual. Imej Landsat ETM+ dituras menggunakan penuras jenis lingkaran kecerunan (gradient type). Seterusnya proses penyurihan lineamen yang bersaiz $5 \times 5$ mengikut lapan arah mata angin iaitu Utara, Selatan, Timur, Barat, Barat Laut, Tenggara, Barat Daya, Timur Laut dilakukan. Pembetulan surihan lineamen dijalankan secara manual bagi mengurangkan ralat yang berlaku serta bagi mendapatkan hasil lineamen yang 


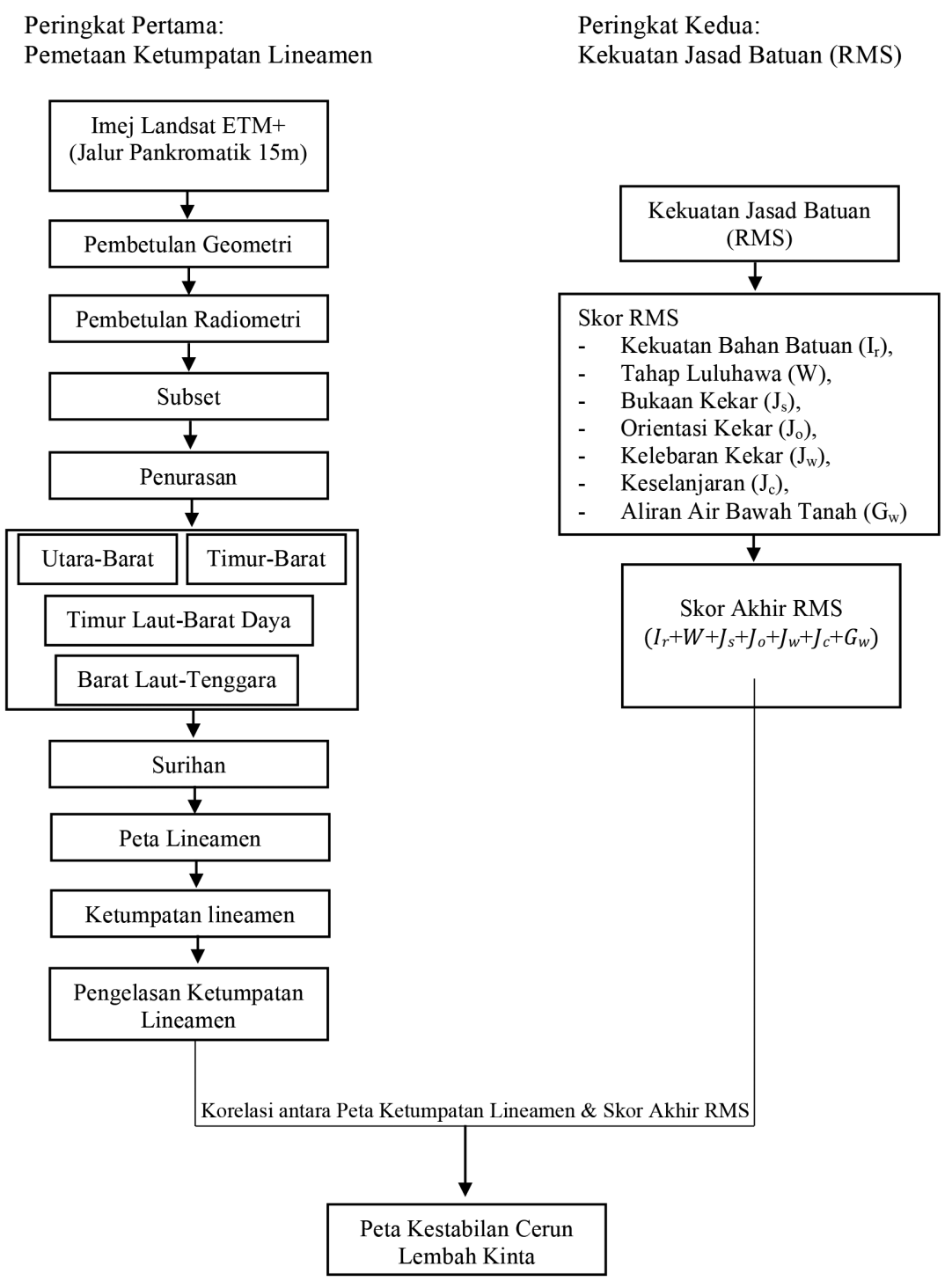

RAJAH 2. Carta alir kaedah penyelidikan

terbaik. Pembetulan lineamen dalam kajian dilakukan berdasarkan panduan yang diberikan oleh Juhari (2003).

Kaedah ketumpatan fishnet digunakan bagi menghasilkan peta ketumpatan lineamen yang menggunakan jumlah panjang garis lineamen yang disurih di dalam grid $100 \times 100 \mathrm{~m}$. Pengelasan dilakukan dengan menggunakan analisis statistik sisihan piawai mengikut ketumpatan lineamen. Kaedah klasifikasi sisihan piawai ini akan menunjukkan berapa banyak ciri nilai atribut yang berbeza daripada nilai min. Kemudiannya nilai min dan sisihan piawai dikira bagi mewujudkan kelas yang berbeza. Lazimnya kelas ini terbahagi kepada beberapa julat antaranya $1,1 / 2,1 / 3$, atau $1 / 4$ dan kelas ini dibezakan daripada segi warna (ESRI 2012). Persilangan lineamen yang tinggi dalam grid $100 \times 100 \mathrm{~m}$ akan memberi nilai ketumpatan yang tinggi. Peta ketumpatan lineamen yang dihasilkan dibahagikan kepada tiga kelas (rendah, sederhana dan tinggi ) diwakili oleh warna yang berbeza di dalam peta.

\section{PERINGKAT KEDUA: KEKUATAN JASAD BATUAN (RMS)}

Kekuatan Jasad Batuan yang diperkenalkan oleh Selby (1980) telah digunakan bagi menilai tahap kestabilan cerun dan memberi petunjuk penting dalam memahami profil cerun perbukitan batu kapur Lembah Kinta. Setiap stesen dinilai dan dicerap sepanjang 20-30 m bergantung kepada kebolehcapaian sesuatu kawasan tersebut. Kaedah ini mengguna pakai tujuh parameter jasad batuan bagi menilai kekuatan keseluruhan jasad batuan. Parameter yang digunakan dalam sistem ini ialah kekuatan bahan batuan $\left(\mathrm{I}_{\mathrm{r}}\right)$, tahap luluhawa $(\mathrm{W})$, bukaan kekar, $\left(\mathrm{J}_{\mathrm{s}}\right)$, orientasi kekar $\left(\mathrm{J}_{\mathrm{o}}\right)$, kelebaran $\operatorname{Kekar}\left(\mathrm{J}_{\mathrm{w}}\right)$, keselanjaran $\left(\mathrm{J}_{\mathrm{c}}\right)$ dan aliran air bawah tanah $\left(\mathrm{G}_{\mathrm{w}}\right)$. Jadual 2 menunjukkan keseluruhan parameter yang dinilai di lapangan.

Setiap parameter yang dinilai dikelaskan kepada lima kumpulan yang berbeza dan setiap kumpulan mempunyai nilai skor ' $r$ ' bagi setiap kelas parameter yang berbeza. Seterusnya setiap skor yang dinilai dijumlahkan bagi memperoleh skor akhir bagi setiap cerun yang dinilai. 
JADUAL 2. Menunjukkan Pengelasan dan skor bagi Kekuatan Jasad Batuan (RMS)

\begin{tabular}{|c|c|c|c|c|c|}
\hline Parameter & Sangat Kuat & Kuat & Sederhana & Lemah & Sangat Lemah \\
\hline $\begin{array}{l}\text { Keutuhan Jasad } \\
\text { Batuan (Tukul } \\
\text { Schmidt Jenis-N) }\end{array}$ & $100-60$ & $60-50$ & $50-40$ & $40-35$ & $35-10$ \\
\hline Perkadaran & $r: 20$ & $\mathrm{r}: 18$ & r: 14 & r: 10 & $\mathrm{r}: 5$ \\
\hline $\begin{array}{c}\text { Tahap } \\
\text { Luluhawa }\end{array}$ & Tidak Luluhawa & $\begin{array}{c}\text { Sedikit } \\
\text { Luluhawa }\end{array}$ & $\begin{array}{l}\text { Sederhana } \\
\text { Luluhawa }\end{array}$ & Sangat Luluhawa & $\begin{array}{c}\text { Luluhawa } \\
\text { Sepenuhnya }\end{array}$ \\
\hline Perkadaran & $\mathrm{r}: 10$ & $\mathrm{r}: 9$ & $\mathrm{r}: 7$ & $\mathrm{r}: 5$ & $\mathrm{r}: 3$ \\
\hline Jarak Bukaan Kekar & $>3 \mathrm{~m}$ & $3-1 \mathrm{~m}$ & $1-0.3 \mathrm{~m}$ & $300-50 \mathrm{~mm}$ & $<50 \mathrm{~mm}$ \\
\hline Perkadaran & $\mathrm{r}: 30$ & $\mathrm{r}: 28$ & $\mathrm{r}: 21$ & r: 15 & $\mathrm{r}: 8$ \\
\hline Arah Kekar & $\begin{array}{l}\text { Sangat Baik. } \\
\text { Kemiringan } \\
\text { curam ke dalam } \\
\text { cerun. Kekar } \\
\text { saling kunci. }\end{array}$ & $\begin{array}{c}\text { Baik. } \\
\text { Kemiringan } \\
\text { sederhana ke } \\
\text { dalam cerun }\end{array}$ & $\begin{array}{l}\text { Memuaskan. } \\
\text { Kemiringan } \\
\text { melintang; hampir } \\
\text { menegak (batuan } \\
\text { keras sahaja) }\end{array}$ & $\begin{array}{c}\text { Tidak Baik. } \\
\text { Kemiringan } \\
\text { sederhana terkeluar } \\
\text { dari cerun }\end{array}$ & $\begin{array}{l}\text { Sangat Tidak Baik. } \\
\text { Kemiringan curam } \\
\text { terkeluar dari cerun }\end{array}$ \\
\hline Perkadaran & $r: 20$ & $\mathrm{r}: 18$ & r: 14 & $\mathrm{r}: 9$ & $\mathrm{r}: 5$ \\
\hline Lebar Kekar & $<0.1 \mathrm{~mm}$ & $0.1-1.0 \mathrm{~mm}$ & $1-5 \mathrm{~mm}$ & $5-20 \mathrm{~mm}$ & $>20 \mathrm{~mm}$ \\
\hline Perkadaran & $\mathrm{r}: 7$ & $\mathrm{r}: 6$ & $\mathrm{r}: 5$ & $\mathrm{r}: 4$ & $\mathrm{r}: 2$ \\
\hline $\begin{array}{c}\text { Ketakselanjaran } \\
\text { Kekar }\end{array}$ & Tidak Selanjar & Sedikit Selanjar & Selanjar, Tiada Isian & Selanjar, Isian Nipis & Selanjar, Isian Tebal \\
\hline Perkadaran & $\mathrm{r}: 7$ & $\mathrm{r}: 6$ & r: 5 & $\mathrm{r}: 4$ & $\mathrm{r}: 1$ \\
\hline $\begin{array}{c}\text { Aliran Air Bawah } \\
\text { Tanah }\end{array}$ & Tiada & $\begin{array}{c}\text { Terdapat Kesan } \\
\text { Aliran }\end{array}$ & $\begin{array}{l}\text { Sedikit }<251 / \\
\min / 10 \mathrm{~m}^{2}\end{array}$ & $\begin{array}{c}\text { Sederhana } 25-1251 / \\
\min / 10 \mathrm{~m}^{2}\end{array}$ & $\begin{array}{c}\text { Sangat Banyak } \\
>1251 / \mathrm{min} / 10 \mathrm{~m}^{2}\end{array}$ \\
\hline Perkadaran & $\mathrm{r}: 6$ & $\mathrm{r}: 5$ & $\mathrm{r}: 4$ & $\mathrm{r}: 3$ & $\mathrm{r}: 1$ \\
\hline Jumlah Perkadaran & $100-91$ & $90-71$ & $70-51$ & $50-26$ & $<26$ \\
\hline
\end{tabular}

Sumber: Diubahsuai daripada Selby (1980)

Nilai skor RMS yang digunakan akan menunjukkan keadaan cerun yang dinilai. Skor akhir dikira berdasarkan persamaan berikut:

$$
R M S=I_{r}+W+J_{s}+J_{o}+J_{w}+J_{c}+G_{w^{*}}
$$

Akhir sekali, peta ketumpatan lineamen dan RMS dikorelasi secara langsung. Keputusan akhir bagi korelasi antara ketumpatan lineamen dan analisis RMS adalah berdasarkan kepada peratusan ketepatan antara kedua-dua kaedah yang dijalankan.

\section{HASIL DAN PERBINCANGAN}

Penilaian di lapangan telah dijalankan di beberapa lokasi yang dikenal pasti berlakunya jatuhan batuan berdasarkan rekod lepas. Kesemua lokasi ini dipilih berdasarkan kepada jarak yang hampir dengan jalan raya dan juga kawasan yang telah dibangunkan (seperti kawasan rumah, kedai dan kilang). Bilangan stesen berserta gunung yang dinilai ditunjukkan dalam Jadual 3. Manakala lokasi bagi setiap stesen ditunjukkan dalam Rajah 1 .

Jumlah keseluruhan lineamen yang disurih adalah sebanyak 599 lineamen dengan panjang keseluruhan adalah 317 km. Rajah 3(a), 5(b), 7(c), dan 9(d) menunjukkan lineamen yang disurih di kawasan Lembah Kinta. Manakala bagi peta ketumpatan lineamen, tiga jenis kelas ketumpatan dikelaskan kepada rendah (137.0-84.23) m, sederhana (84.22-46.83) $\mathrm{m}$ dan tinggi (46.82-0.0) $\mathrm{m}$. Berdasarkan peta ketumpatan lineamen yang dihasilkan (Rajah 4(a), 6(b), 8(c) dan 10(d)), didapati bahawa lineamen paling tumpat yang mewakili kelas lemah terdapat pada Gunung Rapat, Datok dan Tempurung. Manakala Gunung Lang, A dan Panjang pula mempunyai lineamen yang sederhana tumpat dengan kestabilan cerun di kawasan tersebut berada pada tahap sederhana.

JADUAL 3. Bilangan stesen yang dinilai bagi setiap gunung batu kapur

\begin{tabular}{ll}
\hline Gunung & Indikator Stesen \\
\hline Gunung Rapat & R1, R2, R3 \\
Gunung Lang & L1, L2 \\
Gunung A & Pi1 \\
Gunung Datok & D1, D2 \\
Gunung Kandu & K1, K2 \\
Gunung Tempurung & T1 \\
Gunung Panjang & $\mathrm{Pj} 1$ \\
\hline
\end{tabular}




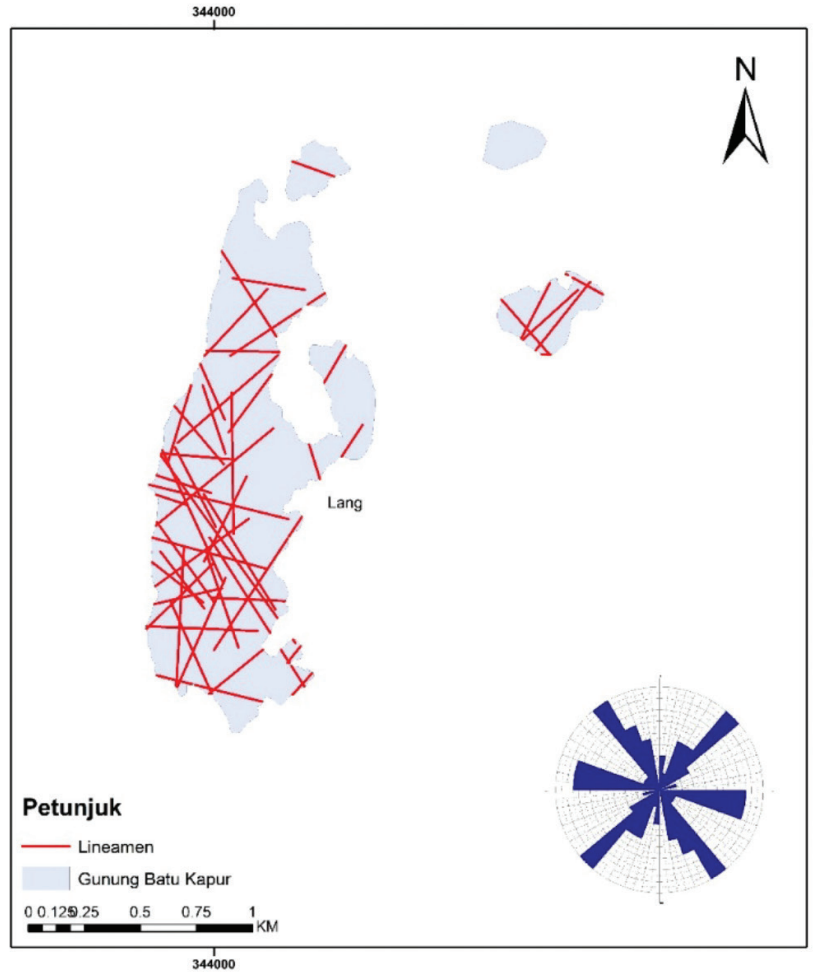

RAJAH 3(a). (Kiri) Lineamen yang dihasilkan berserta gambar rajah mawar bagi Gunung Lang.

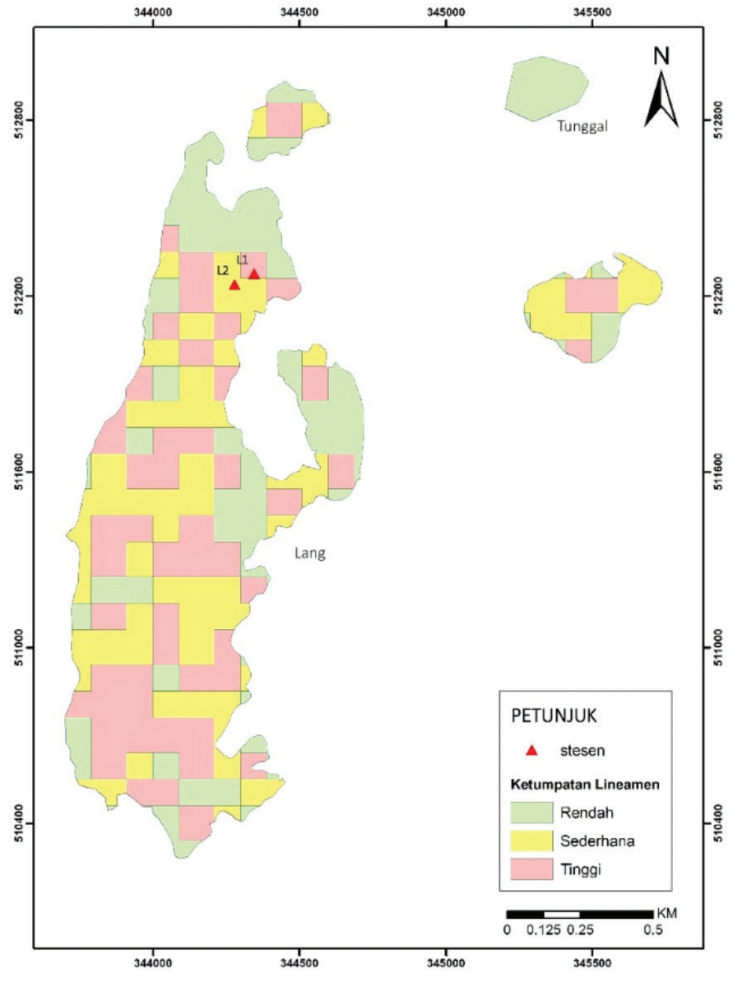

RAJAH 4(a). (Kanan) Peta Ketumpatan Lineamen bagi stesen L1 \& L2 di Gunung Lang

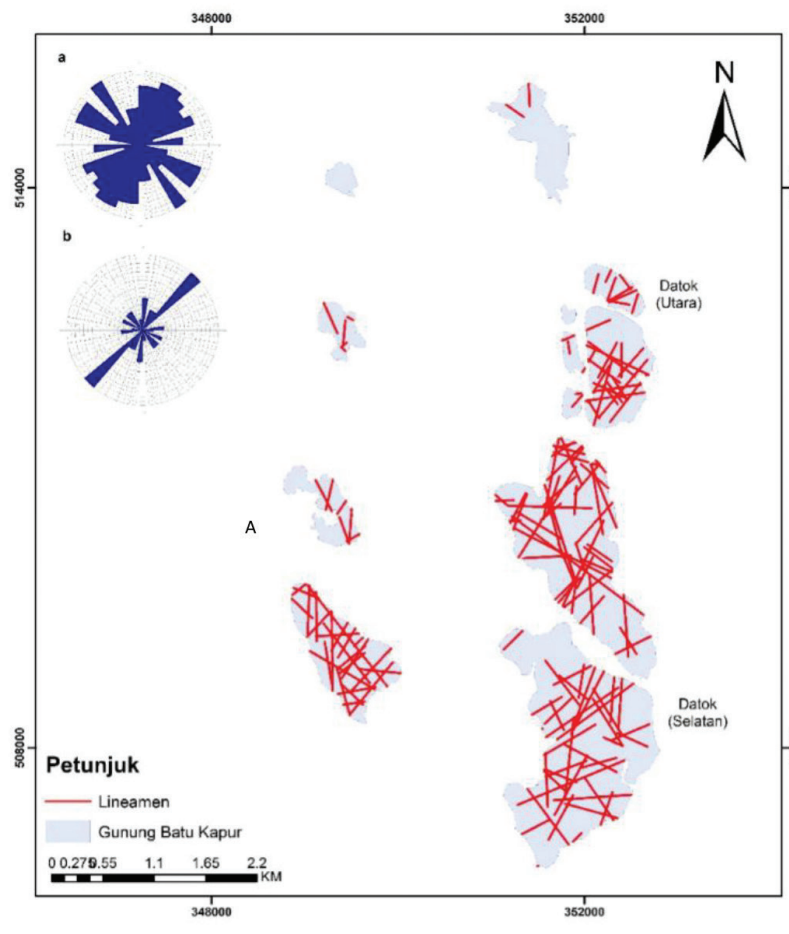

RAJAH 5(b). (Kiri) Lineamen yang dihasilkan berserta gambar rajah mawar bagi Gunung Datok (a) \& A (b).

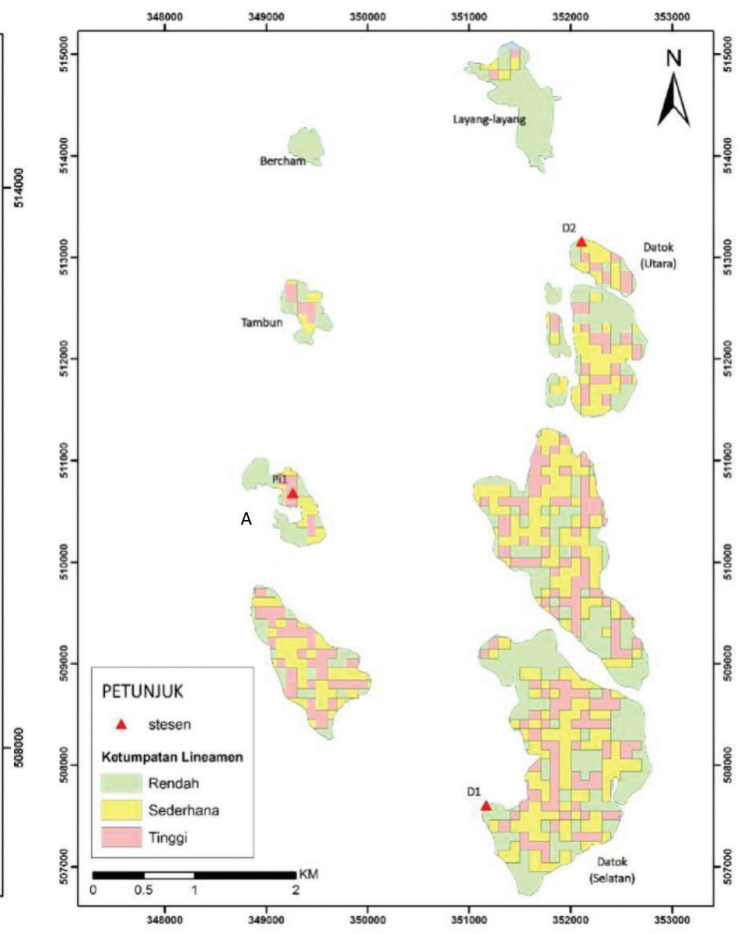

RAJAH 6(b). (Kanan) Peta Ketumpatan Lineamen bagi stesen Pi1 dan D1 \& D2 


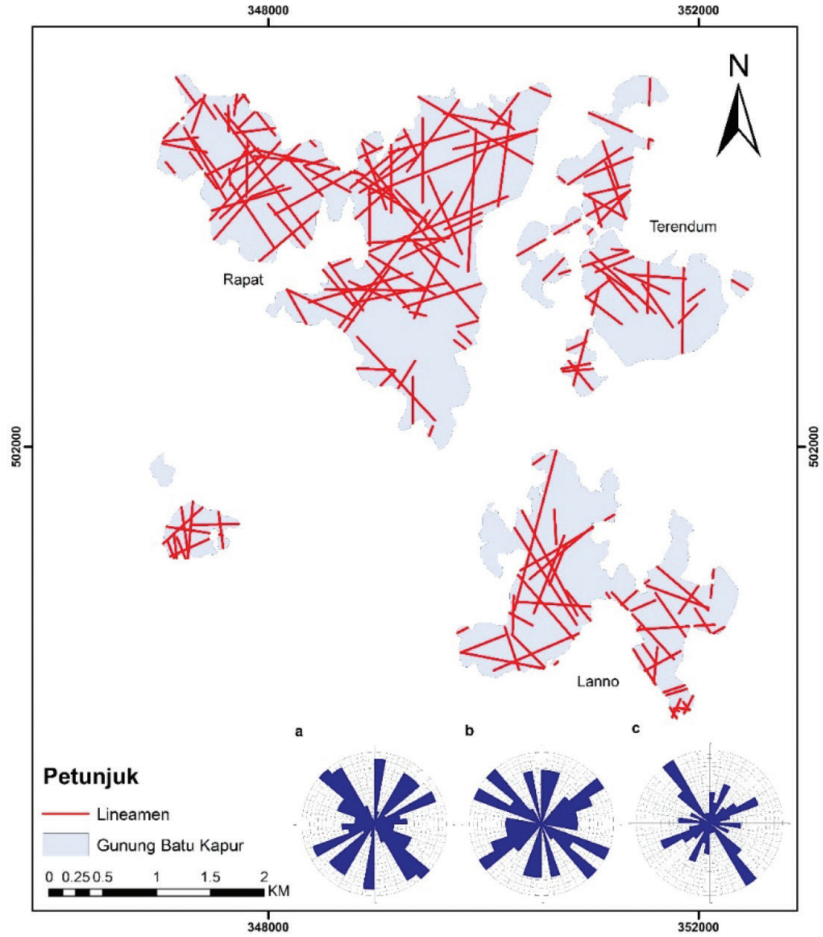

RAJAH 7(c). (Kiri) Lineamen yang dihasilkan berserta gambar rajah mawar bagi Gunung Rapat (a), Terendum (b) \& Lanno (c).

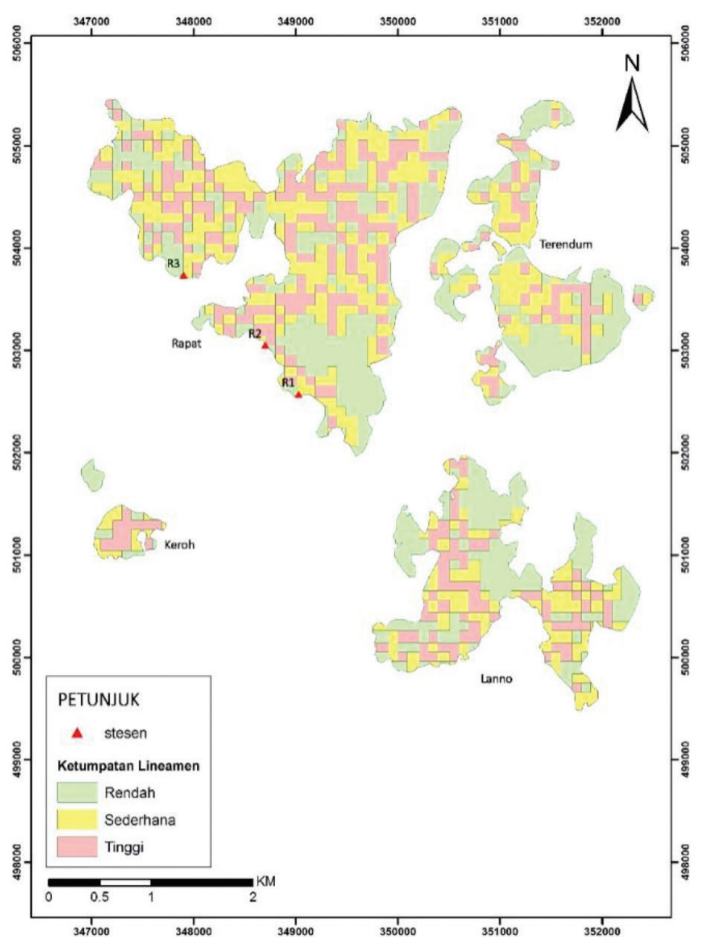

RAJAH 8(c). (Kanan) Peta Ketumpatan Lineamen bagi stesen R1, R2 \& R3 di Gunung Rapat

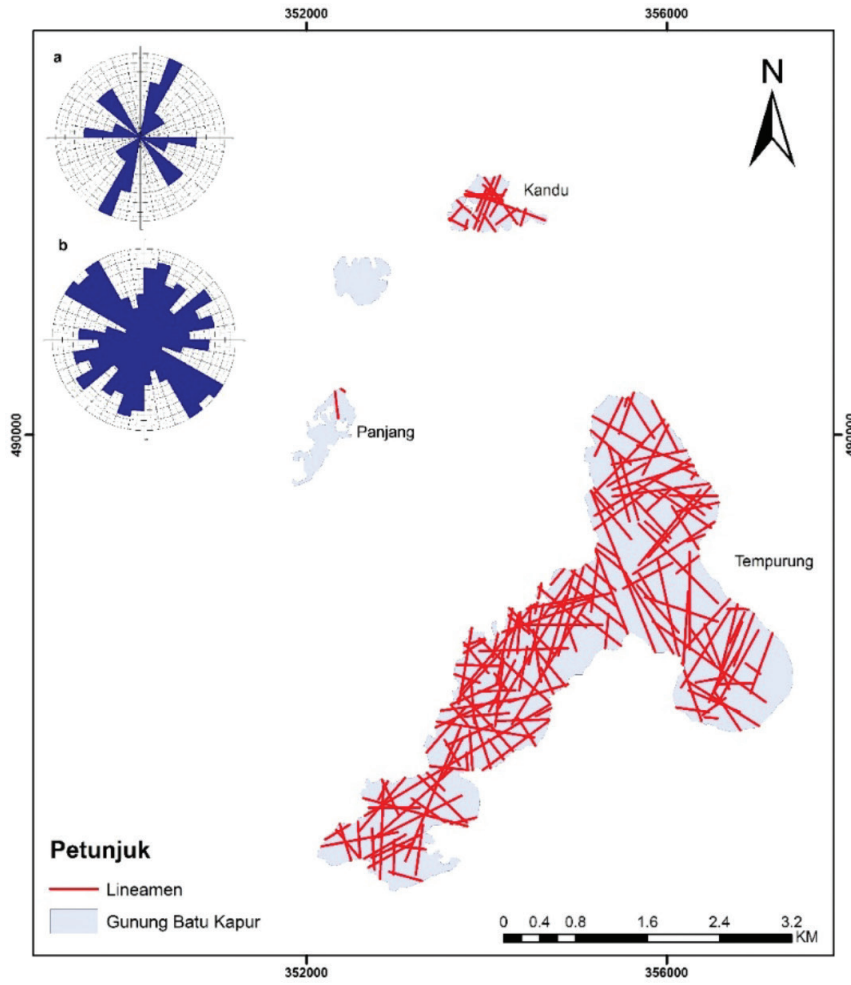

RAJAH 9. (d) (Kiri) Lineamen yang dihasilkan berserta gambar rajah mawar bagi Gunung Kandu (a) \& Gunung Tempurung (b)

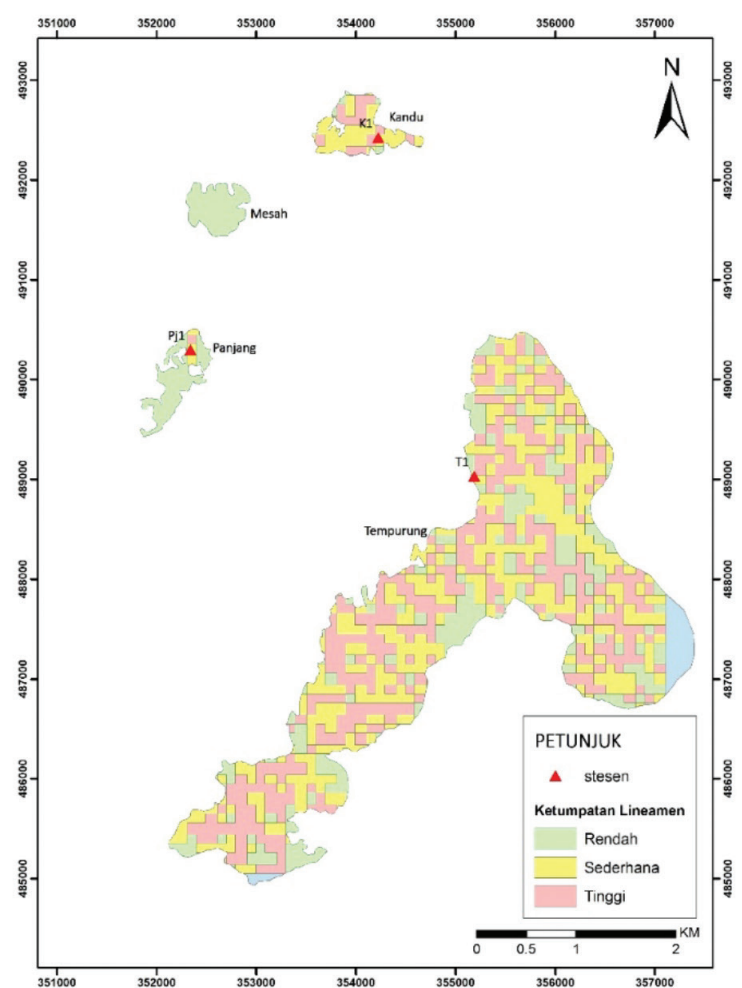

RAJAH 10(d) (Kanan) Peta Ketumpatan Lineamen bagi stesen T1, Pj1 dan K1 
Berdasarkan penilaian RMS, tahap kestabilan cerun berada pada tahap lemah hingga sederhana. Hanya Gunung Lang sahaja mencatatkan tahap kestabilan yang lemah manakala enam gunung yang lain (Gunung Rapat, A, Datok, Kandu, Tempurung dan Panjang) berada pada tahap sederhana. Kesemua parameter yang dicerap direkodkan dalam Jadual 4.

Terdapat sedikit perbezaan antara skor bagi keseluruhan bukit batu kapur yang dicerap melalui kaedah lapangan dan juga dengan menggunakan peta ketumpatan lineamen. Bagi data ketumpatan lineamen, keputusan akhir kekuatan jasad batuan berada pada tahap sederhana (Gunung Rapat, A, Dato, Kandu, Tempurung dan Panjang) sehingga tinggi (Gunung dan A). Namun begitu, pemerhatian di lapangan mendapati bahawa julat kekuatan jasad batuan adalah dalam lingkungan lemah (Gunung Lang) hingga sederhana (Gunung Rapat, A, Dato dan Kandu). Walaupun penggunaan penderiaan jauh mampu mencerap kawasan yang sangat luas, kaedah lapangan mampu memberikan data yang lebih tepat dan terperinci mengenai keadaan cerun dan kestabilan cerun bagi setiap kawasan yang dicerap. Jadual 5 menunjukkan keseluruhan kawasan kajian yang dicerap berserta perbezaan antara analisis RMS dan peta ketumpatan lineamen.

Seterusnya, kajian ini mendapati $73 \%$ daripada keseluruhan stesen yang dinilai di lapangan mempunyai kelas yang sama dengan hasil daripada peta ketumpatan lineamen. Berdasarkan kajian Singh et al. (2008), tahap kejituan antara hasil lapangan dan model ketumpatan lineamen mestilah melebihi $70 \%$ bagi membolehkan sesuatu model itu diterima pakai. Manakala 27\% (stesen L2, Pi1 dan D1) yang dicerap tidak mempunyai korelasi yang sama antara RMS dan juga peta ketumpatan lineamen yang dihasilkan. Ini mungkin disebabkan oleh faktor resolusi imej yang kurang memuaskan pada sebahagian kawasan menyebabkan lineamen sukar dikenal pasti. Tambahan pula, melalui kerja lapangan yang dilakukan hampir kesemua stesen yang dinilai terdapat tumbuhan yang meliputi struktur cerun dan ini mengakibatkan lineamen kurang jelas kelihatan. Di samping itu juga, pemerhatian di lapangan memberi gambaran struktur cerun yang sangat jelas yang mampu memberi pandangan struktur cerun secara menegak berbanding penggunaan imej satelit yang memberikan imej pada pandangan atas

JADUAL 4. Klasifikasi dan skor jasad batuan berdasarkan RMS bagi setiap stesen

\begin{tabular}{cccccccccc}
\hline Stesen & Ir & W & Js & Jo & Jw & Jc & Gw & Jumlah Perkadaran & Klasifikasi \\
\hline R1 & 10 & 7 & 21 & 5 & 2 & 5 & 5 & 55 & Sederhana \\
R2 & 10 & 7 & 15 & 5 & 4 & 5 & 5 & 51 & Sederhana \\
R3 & 10 & 7 & 21 & 9 & 4 & 1 & 5 & 57 & Sederhana \\
L1 & 5 & 9 & 15 & 5 & 2 & 5 & 6 & 47 & Lemah \\
L2 & 5 & 7 & 15 & 9 & 2 & 5 & 6 & 49 & Lemah \\
Pi1 & 5 & 9 & 15 & 14 & 2 & 4 & 6 & 55 & Sederhana \\
D1 & 10 & 5 & 21 & 5 & 2 & 5 & 6 & 54 & Sederhana \\
D2 & 5 & 9 & 21 & 14 & 4 & 4 & 6 & 63 & Sederhana \\
K1 & 10 & 7 & 21 & 5 & 4 & 4 & 5 & 56 & Sederhana \\
K2 & 10 & 7 & 21 & 5 & 4 & 4 & 5 & 56 & Sederhana \\
T1 & 14 & 7 & 21 & 9 & 2 & 4 & 4 & 61 & Sederhana \\
Pj1 & 14 & 7 & 21 & 5 & 2 & 5 & 5 & 59 & Sederhana \\
\hline
\end{tabular}

$\mathrm{I}_{\mathrm{r}}=$ Keutuhan Jasad Batuan, $\mathrm{W}=$ tahap luluhawa, $\mathrm{J}_{\mathrm{s}}=$ jarak belahan kekar, $\mathrm{J}_{\mathrm{o}}=$ arah kekar, $\mathrm{J}_{\mathrm{w}}=$ lebar kekar, $\mathrm{J}_{\mathrm{c}}=$ ketakselanjaran kekar dan $\mathrm{G}_{\mathrm{w}}=$ aliran air bawah tanah

JADUAL 5. Perbezaan antara analisis RMS \& Peta ketumpatan lineamen

\begin{tabular}{lcccc}
\hline Gunung & Stesen & RMS & $\begin{array}{c}\text { Peta ketumpatan } \\
\text { lineamen (PKL) }\end{array}$ & $\begin{array}{c}\text { Kestabilan cerun } \\
\text { berdasarkan PKL }\end{array}$ \\
\hline Gunung Rapat & R1 & Sederhana & Sederhana & Sederhana \\
& R2 & Sederhana & Sederhana & Sederhana \\
R3 & Sederhana & Sederhana & Sederhana \\
Gunung Lang & L1 & Lemah & Tinggi & Lemah \\
Gunung A & L2 & Lemah & Sederhana & Sederhana \\
Gunung Datok & Pi1 & Sederhana & Tinggi & Lemah \\
Gunung Kandu & D1 & Sederhana & Rendah & Kuat \\
Gunung Tempurung & D2 & Sederhana & Sederhana & Sederhana \\
Gunung Panjang & K1 & Sederhana & Sederhana & Sederhana \\
\hline
\end{tabular}


cerun sahaja. Ini jelas ditunjukkan melalui hasil pada stesen L2, dengan Peta Ketumpatan Lineamen yang dihasilkan memberi nilai kekuatan batuan yang sederhana berbanding nilai RMS yang diperoleh di lapangan yang berada pada tahap lemah.

Secara keseluruhannya tahap kestabilan cerun perbukitan batu kapur di Lembah Kinta berada pada tahap Lemah hingga Sederhana. Analisis RMS yang dijalankan sangat berkait rapat dengan ciri kekar yang terdapat di cerun. Ciri ini mempengaruhi nilai skor RMS yang hampir keseluruhan cerun dicerap memiliki nilai tahap kekar yang lemah hingga sederhana bagi setiap stesen tersebut. Keseluruhan skor RMS bagi tujuh gunung batu kapur yang dicerap mendapati Gunung Lang dikelaskan sebagai lemah. Manakala Gunung Rapat, A, Datok, Kandu, Tempurung dan Panjang dikelaskan sebagai sederhana. Namun begitu, pếrbukitan batu kapur di Lembah Kinta memperlihatkan orientasi kekar yang tidak baik dengan arah kemiringan yang mengarah keluar dari cerun. Faktor semula jadi seperti proses luluhawa mengakibatkan bukaan kekar semakin besar di samping aktiviti manusia seperti gegaran daripada letupan kuari berdekatan meningkatkan kecenderungan berlakunya jatuhan batuan.

\section{KESIMPULAN}

Secara amnya, tahap kestabilan cerun di perbukitan batu kapur berada pada tahap lemah hingga sederhana dengan potensi berlakunya jatuhan batuan adalah pada kawasan yang berada pada tahap lemah seperti di stesen L1 dan Pi1. Oleh itu, kestabilan cerun batu kapur di Lembah Kinta dipengaruhi secara langsung oleh ketumpatan lineamen rantau. Peta ketumpatan lineamen yang dihasilkan mampu memberi petunjuk awal tahap kestabilan cerun sesuatu kawasan sebelum kajian terperinci di lapangan dijalankan.

\section{PENGHARGAAN}

Setinggi-tinggi penghargaan dan terima kasih kepada Kementerian Sains, Teknologi dan Inovasi (MOSTI) yang telah memberikan peruntukan melalui geran penyelidikan Sciencefund (Kod Geran:06-01-02-SF1140) dan UKM melalui geran penyelidikan GUP-2016-024 bagi membiayai penyelidikan ini.

\section{RUJUKAN}

Abdullah Sani Hashim. 1991. Kajian Penilaian Potensi Batu Kapur di Perak. Jabatan Penyiasatan Kajibumi Malaysia. 21/1991.

Aw, P.C. 1996. Limestone resource: Abundance or scarcity a matter of perspective. In International Symposium on Limestone. Universiti Sains Malaysia \& Institute of Quarrying Malaysia, Subang Jaya.

Aw, P.C. \& Ooi, A.C. 1979. A real distribution of limestone and dolomite in the Kinta District, Perak - A case for economic exploitation. In Geological Survey Malaysia - Annual Report. Ipoh: Geological Survey Department Malaysia.

Chung, S.K. 1981. Laporan Tahunan. Penyiasatan Kajibumi Malaysia: Kementerian Perusahaan Utama.

Chow, W.S. 1995. Sinkholes and Rockfalls in the Kinta Valley. Geological Survey Department, Malaysia. 6/1995.

Chow, W.S. \& Majid Sahat. 1988. Batu runtuh di Gunong Tunggal, Gopeng, Perak. Laporan Penyiasatan Kajibumi. Jabatan Kajibumi Malaysia. 1/1988.

ESRI. 2012. ArcGIS Resources: Classifying Numerical Fields for Graduated Symbology. http://resources.arcgis.com/en/ help/main/10.1/index.html\#//00s50000001r000000. Diakses pada 1 Julai 2014.

Foo, K.Y. 1983. The Palaeozoic sedimentary rocks of Peninsular Malaysia - Stratigraphy and correlation. In Proceeding of the Workshop on Stratigraphic Correlation of Thailand and Malaysia 1: 1-19.

Hashim, A.S. 1991. Limestone potential assessment in Perak. Geological Survey Report. Minerals \& Geoscience Department. Malaysia 21/1991.

Hutchison, C.S. \& Tan, D.N.K. 2009. Geology of Peninsular Malaysia. Universiti of Malaya.

Ingham, F.T. \& Bradford,E.F. 1960. Geology \& Mineral Resource of the Kinta Valley, Perak. District Memoir 9. Federal of Malaya Geological Survey.

Jabatan Mineral \& Geosains Negeri Perak. 2009. Penyiasatan Geologi dan Zon Keselamatan Bukit Batu Kapur Gunung Sentang dan Gunung Tasek, Mukim Ulu Kinta, Ipoh, Perak.

Juhari Mat Akhir. 2003. Lineament mapping from satellite remote sensing images: A suggestion for a more objective method. International Symposium and Exibition on Geoinformation. 13-14 October, Shah Alam, Malaysia hlm. 32-44.

Metcalfe, I. 1981. Permian and Early Triassic conodonts from Northwest Peninsular Malaysia. Bull. Geol. Soc. Malaysia 14: 119-126.

Mohd Shafeea Leman. 2013. Proposed Kinta Valley Geopark - Utilizing geological resources for environmental quality improvement and society well being enhancement. Keynote Address. National Geoscience Conference, 8-9 June, Kinta Riverfront Hotel \& Suites, Ipoh, Perak. hlm 1-3.

Simon, N., Ghani, M.F.A., Lai, G.T., Rafek, A.G., Hussin, A., Roslee, R. \& Ern,L.K. 2015. Assessment of rockfall potential of limestone hills in the Kinta Valley. Journal of Sustainability Science and Management 10(2): 24-34.

Selby, M.J. 1980. A rock mass strength classification for geomorphic purposes: With tests from Antarctica and New Zealand. Z. Geomorphol. 24: 31-51.

Singh, H., Huat, B.B.K. \& Jamaludin, S. 2008. Slope assessment system: A review and evaluation of current techniques used for cut slopes in the mountainous terrain of West Malaysia. Electronic Journal of Geotechnical Engineering 13: 1-24.

Suntharalingam, T. 1968. Upper Palaeozoic stratigraphy of the area West of Kampar, Perak. Geological Society of Malaysia Bulletin 1: 1-15.

Tuan Rusli Mohammed \& Ahmad Khairut Termizi. 2012a. Laporan Ringkas Kejadian Bencana Geologi di Kawasan Kilang Yee Lee Edible Oils Sdn. Bhd. Jabatan Mineral \& Geosains, Malaysia, Perak.

Tuan Rusli Mohammed \& Ahmad Khairut Termizi. 2012b. Laporan Ringkas Kejadian Bencana Geologi Di Gua Tempurung, Kampar, Perak. Jabatan Mineral \& Geosains, Malaysia, Perak. 
Muhammad Fahmi Abdul Ghani*, Norbert Simon \& Goh Thian Lai

Pusat Pengajian Sains Sekitaran dan Sumber Alam Fakulti Sains dan Teknologi

Universiti Kebangsaan Malaysia

43600 Bangi, Selangor Darul Ehsan

Malaysia.

Tuan Rosli Tuan Mohamed

Jabatan Mineral dan Geosains Perak

Jalan Sultan Azlan Shah

31400 Ipoh, Perak Darul Ridzuan

Malaysia
Abdul Ghani Rafek

Jabatan Geosains, Universiti Teknologi PETRONAS

Bandar Seri Iskandar,

31750 Tronoh, Perak Darul Ridzuan

Malaysia

*Pengarang untuk surat-menyurat; email: fahmighani@icloud. com

Diserahkan: 25 Mac 2016

Diterima: 19 Ogos 2016 